\title{
EVALUATION OF THE GROUNDWATER QUALITY IN A CLOSED INDUSTRIAL LANDFILL
}

\author{
SENOU ISSAKA ${ }^{1}$, NARCIS BÂRSAN ${ }^{2 *}$, VALENTIN NEDEFF ${ }^{2}$, \\ SOME N. ANTOINE ${ }^{1}$, NACRO H. BISMARCK ${ }^{3}$
}

\author{
${ }^{1}$ Laboratory of Natural Systems, Agrosystems and engineering of environment, Polytechnic \\ University of Bobo, 01 B.P. 1091 Bobo Dioulasso 01, Burkina Faso \\ 2"Vasile Alecsandri" University of Bacau, Bacau, 600011, Romania
}

${ }^{3}$ Laboratory for study and research on soil fertility, Polytechnic University of Bobo, 01 B.P. 1091 BoboDioulasso 01, Burkina Faso

\begin{abstract}
The study parameters: pH, conductivity, salinity, Total Dissolved Solids (TDS), Turbidity, Total Suspended Solids (TSS) and Chemical Oxygen Demand (COD) of groundwater in a closed industrial landfill, subject to the waste discharges of city of Bacau (East Romania), shows that the water quality of the different sampling points is variable. This difference is noted at the level of conductivity, TDS, turbidity, TSS and COD. These differences, however parameters are substantially higher compared the value of the legislation in groundwater Romania. Salinity remains relatively high at the point of sample $\mathrm{P} 1$ (0.7). The $\mathrm{pH}$ values are comprising in the range of reference values (6.5 to 7.4). The results also showed very strong correlations ( $r>0.8$ ) between Conductivity-Salinity, Conductivity -TDS, Salinity, TDS, Turbidity.-TSS, COD and TSS-Turbidity-COD. The strong correlation $(0.5<\mathrm{r}>0.8)$ were noted between Turbidity- Conductivity, TurbiditySalinity, Turbidity, TDS, TSS conductivity, TSS-Salinity, TSS, TDS, COD, conductivity, salinity, COD, COD-TDS. Principal Component Analysis (PCA) also highlighted groundwater mineralization events of this landfill and possible pollution by organic matter.
\end{abstract}

Keywords: closed industrial landfill, groundwater quality parameters

\section{INTRODUCTION}

Rapid urbanization creates big quantities of waste in large cities. These wastes consist primarily of household waste, industrial waste, medical waste, sewage sludge etc. The strategy of prevention and reduction of environmental pollution through waste management through industrial discharge. This form of management creates an indirect pollution of groundwater through precipitation, seepage or leakage of pollutants [1-3]. An obvious alternative method of controlling the pollution of groundwater by industrial discharges is to retrieve these water discharges through underground channels. Such methods of storage of groundwater discharges may limit problems concerning water pollution and in some cases could create secondary benefits such as restoration of groundwater and decreased soil pollution [1]. This method may have other benefits such as ecological restoration of site soils and generally reduce the pollutants from waste on the environment by improving living conditions and protect human health $[4,5]$. Waste can also often contain pathogens responsible for diseases [6].

\footnotetext{
${ }^{*}$ Corresponding author, email: narcis.barsan@ub.ro
}

(C) 2016 Alma Mater Publishing House 
In addition, water pollutants can easily migrate into surface water that are consumed by animals, by the bias of the food chain reaches humans [1].

A more comprehensive assessment of the current situation of the groundwater quality of this industrial discharge is of great necessity to safeguard the water table and environments ecosystems. It is in this perspective that we have assessed the quality of groundwater in this industrial landfill closed in Bacau (East Romania) in order to disassemble the dangers of pollution from waste stored. The overall aim of the article is to assess the groundwater quality of this discharge. To achieve this goal, we analyze parameters such as $\mathrm{pH}$, conductivity, turbidity, salinity, TSS, TDS and COD.

\section{EXPERIMENTAL SETUP}

\subsection{The site studied}

The study site $\left(46^{\circ} 31\right.$ '20.04 "N, $\left.26^{\circ} 58^{\prime} 39.79^{\prime \prime} \mathrm{E}\right)$ is located at the south exit of the city of Bacau (Romania). It is an industrial landfill site closed ago 2010 (Figure 1). The entire landfills cover an area of approximately 14.9 hectares. On the site, there are well-developed vegetation.

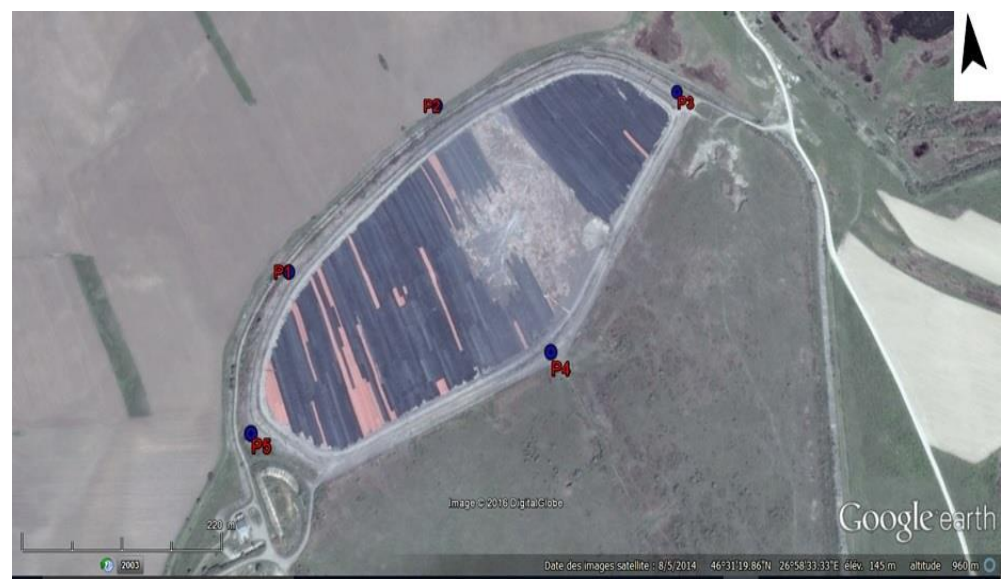

Fig. 1. Site Location map and placement of water sampling points on the map.

\subsection{Presentation of waste types and conditions of the landfill}

The landfill was a part of the heating network infrastructure of Bacau City. Due to restructuring of the city heating system, slag and ash deposit was closed. Ash and slag landfill are hazardous industrial waste disposal, according to HG.349/2005 [7].

The landfill has an area of 46.77 ha with a volume by $3370000 \mathrm{~m}^{3}$ divided in three compartments. The landfill was covered with a layer of soil 40-60 cm and was included in the zonal landscape [7].

\subsection{Analysis of groundwater samples}

Groundwater's samples were taken at a depth of $4 \mathrm{~m}$ from the surface. The site has a system that can retrieve groundwater to prevent various forms of pollution to groundwater. The samples were collected in the five openings of the channels that receive these waters. The water samples were stored in plastic bottles at $4{ }^{\circ} \mathrm{C}$ and transported to the laboratory.

Properties of water described below were determined according to standard procedures published by the French Association of Normalization [6]. The parameters that have the measurement object are $\mathrm{pH}$, conductivity, salinity, TDS, turbidity, TSS and COD. The analyzes were conducted at the Research Laboratory, Department of Environmental Engineering an Mechanical Engineering, "Vasile Alecsandri" University of Bacau, Romania.

PH, conductivity, salinity, TDS were determined by a type of meter WTW 9420 (Figure 2.a). Water turbidity was measured using a turbidity meter type WTW 430IR (Figure 2.b). The determination of COD and TSS water was made by a spectrophotometer DR 3900 (Figure 3). The flocculants were used as cationic organic solutions. These flocculants were in liquid form with concentrations of between 50 and $300 \mathrm{mg} / \mathrm{L}$. 


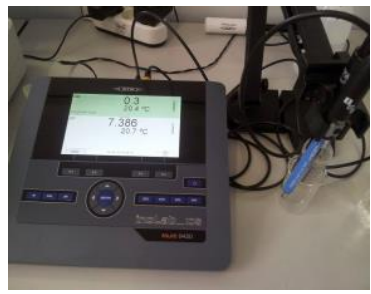

a)

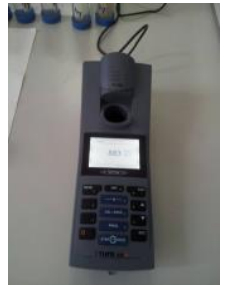

b)

Fig. 2. Mustimeter WTW 430 IR and Turbidity Meter WTW 9420 (laboratory materials).

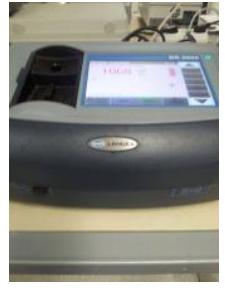

a)

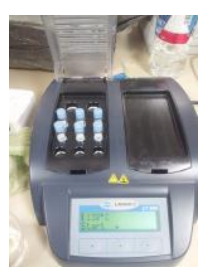

b)

Fig. 3. DR 3900 Spectrophotometer and activator LT 200 (laboratory materials).

\subsection{Statistical and graphical analyses of the results}

The statistical approach is based on the use of Principal Component Analysis (PCA). The eigen values, factorial maps and correlations were obtained using SPSS software version 20. Results of analyzes of physical and chemical parameters of water were also compared with the guide values of Romania [8-9]. The graphics were created with the Origin-Pro version 8.5.0 software.

\section{RESULTS AND DISCUSSION}

\subsection{Physical and chemical parameters of water}

The $\mathrm{pH}$ of the water is slightly alkaline at four sampling points of the site. At point $\mathrm{P} 1$, the $\mathrm{pH}$ is slightly acidic (6.95). It varies between 6.95 and 7.44 at point P1 to point P3 to an average of 7.25 (Figure 4). The values of this parameter are in the range of $\mathrm{pH}$ values tolerated (6.5 to 7.4) for water aquifers by Romania [9].

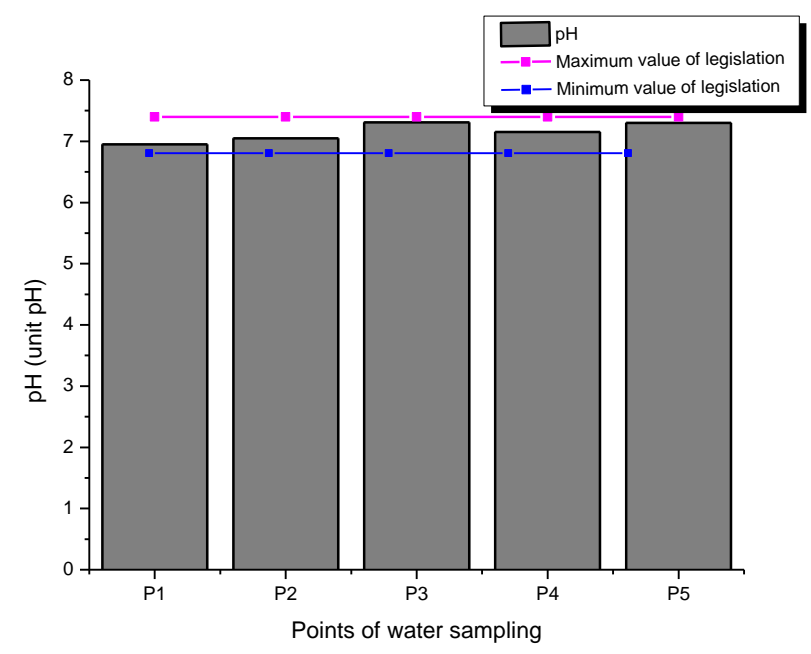

Fig. 4. Evaluation of the $\mathrm{pH}$ values in the monitored points.

The measurement of the conductibility parameter is a good assessment of the degree of mineralization of water where each ion is by its concentration and specific conductivity. The conductivity shows a slight change in the 
chemical composition of water between the points P1, P4 and P5 where values are 1378 respectively; 826 and $836 \mu \mathrm{S} / \mathrm{cm}$ (Figure 5). Points P2 and P3 recorded respectively 398 and $616 \mu \mathrm{S} / \mathrm{cm}$. The average conductivity of $809.6 \mu \mathrm{S} / \mathrm{cm}$ and remains below the standard set by Romania $(1000 \mu \mathrm{S} / \mathrm{cm})$ for water plies [9] (Figure 5). This average is greater than the French norm of $400 \mu \mathrm{S} / \mathrm{cm}[10]$ and smaller than that of Morocco in $2700 \mu \mathrm{S} / \mathrm{cm}[11]$ for the potability of the water. With an average pattern of heavy conductivity, groundwaters of this industrial discharge are strongly mineralized. These results appear identical to those reported by [10] in groundwater in regions of Chaouia (Morocco). These results also corroborate those of $[12,13]$ which showed that the well water showed the highest conductivities.

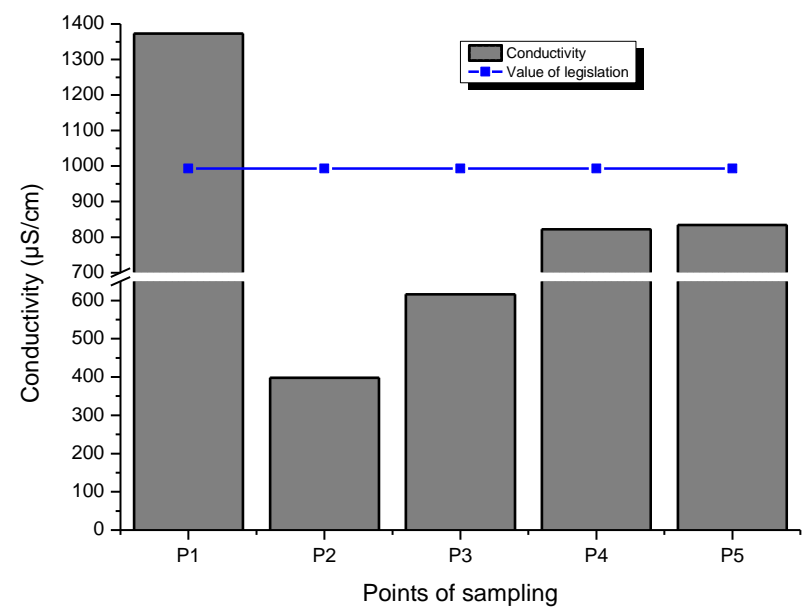

Fig. 5. Evaluation of the conductivity in the monitored points.

TDS determines the total amount of mobile charged ions, including minerals, salts, metals, cations or anions dissolved in water. The TDS of the water ranges from $397 \mathrm{mg} / \mathrm{L}$ at the sampling point P1 and $1456 \mathrm{mg} / \mathrm{L}$ at the point P2. These high values of TDS testify that groundwater in this industrial landfill closed is not pure.

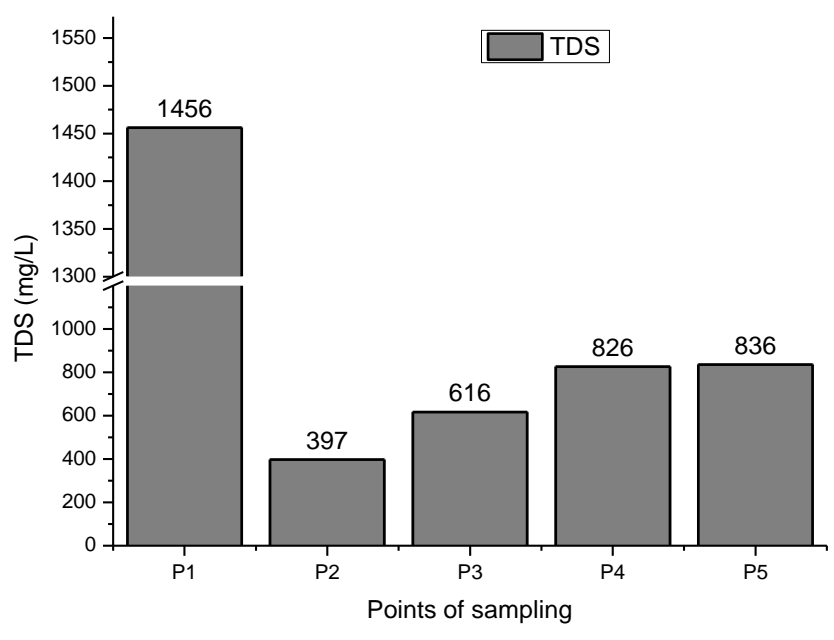

Fig. 6. Evaluation of the TDS in the monitored points.

The values of the salinity are recorded $0.7 ; 0.1 ; 0.2 ; 0.3$ and 0.3 respectively to the points $\mathrm{P} 1, \mathrm{P} 2, \mathrm{P} 3, \mathrm{P} 4$ and P5 (Figure 7). The highest value observed in P1 is due to the higher conductivity at this point. With an average value of 0.32 ; the groundwater salinity is in the standard of that of the fresh waters is 0 to 0.5 (Figure 7). Moreover, the fact that the samples were carried out during the rainy period, the drop in water salinity could also be explained by rainfall inputs, unlike the dry season which occurs elevated this setting helped by strong 
evaporation. The result sets of [13] have shown a salinity of 0.00 in groundwater in the village of Mangouin Yrongouin (western Ivory Coast).

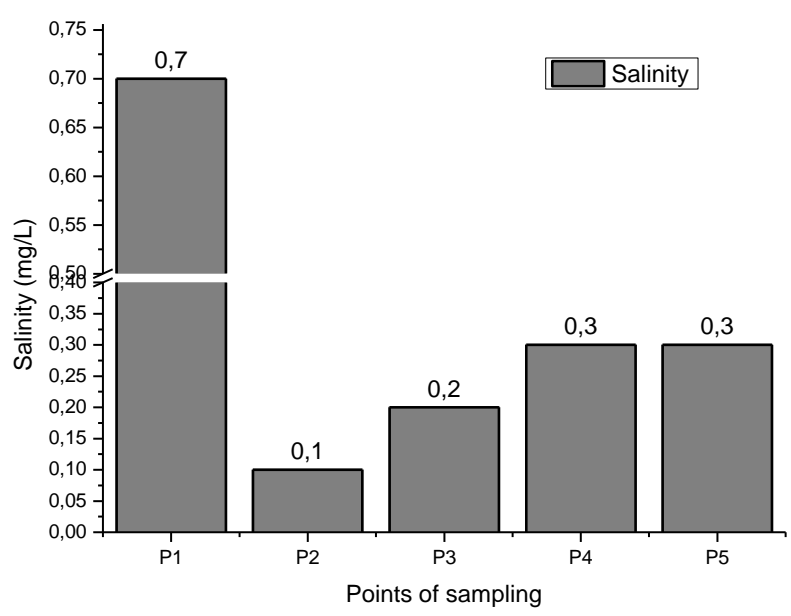

Fig. 7. Evaluation of the samples salinity.

Groundwater of the closed discharge has a turbidity ranging from 780-184 NTU, with an average of 450.4 NTU (Figure 8). This average value very high compared to fixed Romanian standards in the waters tablecloths (5 NTU) shows great turbidity of groundwater of the landfill. This indicates the presence of suspended particles in water (organic debris, clay, microscopic organisms etc.).

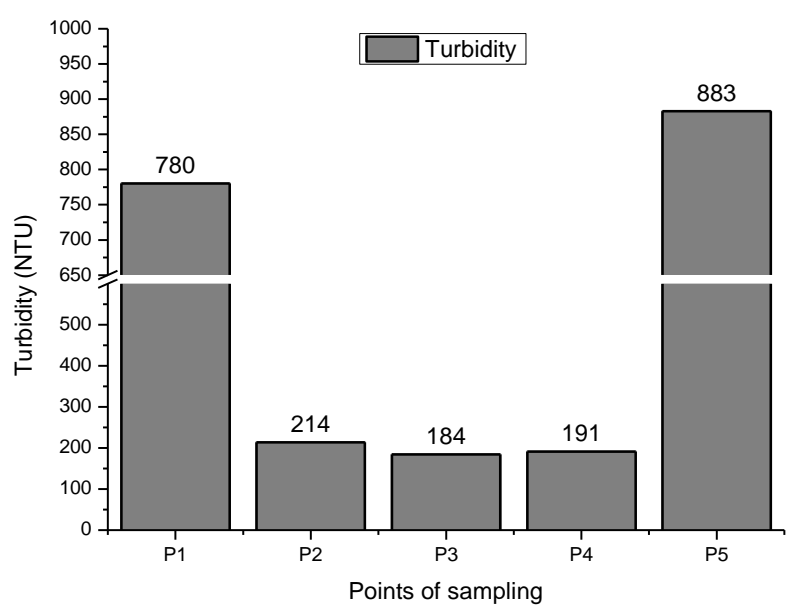

Fig. 8. Evaluation of the samples salinity.

The highest values of the total suspension solids (TSS) were recorded in water sampling points P1 and P5, respectively 1068 and $922 \mathrm{mg} / \mathrm{L}$ (Figure 9). However, the average value at the Five Points (464.4 mg/L) remains slightly higher than that set by Romanian standards [9] which are $429 \mathrm{mg} / \mathrm{L}$.

The chemical oxygen demand (COD) is very variable in the different sampling points. The minimum value is $65.4 \mathrm{mg} / \mathrm{L}$ at $\mathrm{P} 1$ while achieving maximum value is $750 \mathrm{mg} / \mathrm{L}$ (Figure 10). These recorded COD values are largely higher than indicated as Romanian normative value of groundwater is $5 \mathrm{mg} / \mathrm{L}$ [9]. It also remains above the Moroccan standards [11] and French [10] for the potability of the water. 


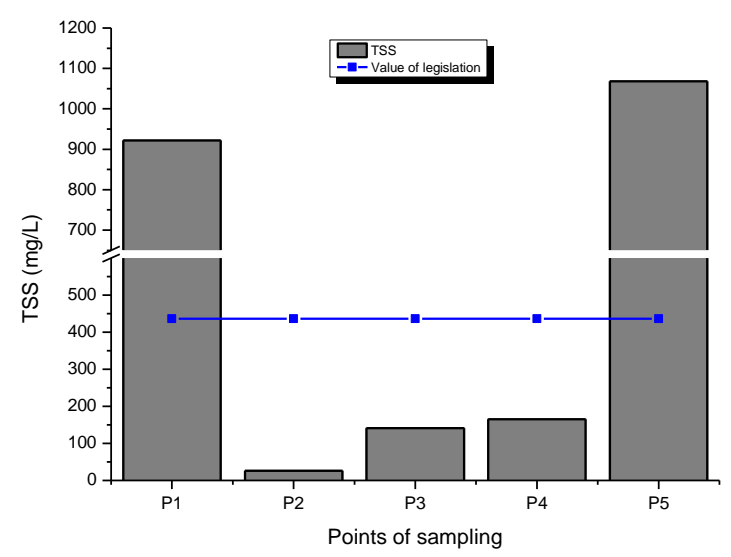

Fig. 9. TSS values in the analyzed samples.

These high values of COD show the important load this groundwater in organic matter. The great variability of the COD at different points of discharge could be linked, firstly, to the rainfall which occurs by a dilution of dissolved and suspended substances and, on the other hand, the source of household contamination or industrial [14].

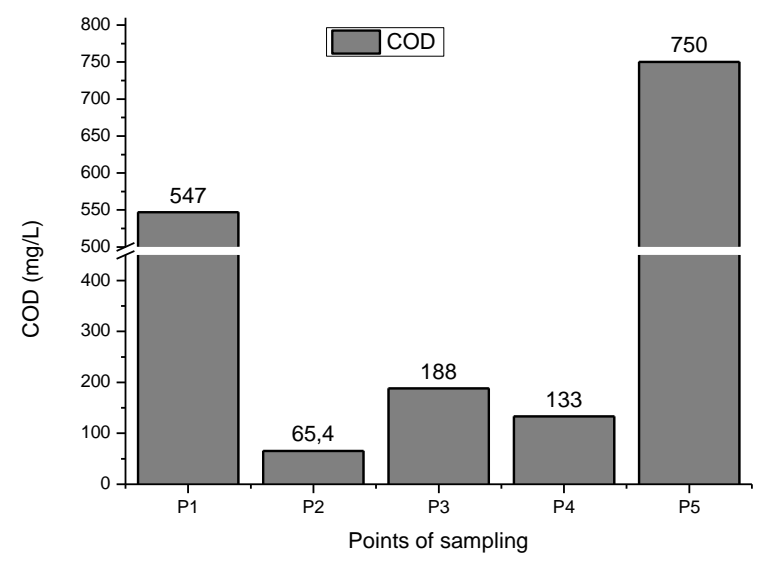

Fig. 10. COD values in the analyzed samples.

\subsection{Results of statistical analysis: Principal Component Analysis (A.C.P)}

Principal Component Analysis (A.C.P) transforms the initial quantitative variables, correlated with each other in new quantitative variables, with principal components [15]. It's a methodology widely used for interpreting hydrochemical data $[16,17]$. The dates used in the statistical analyses were presented also in the Figures 4-10. The values of the statistical factors (eigen values) are shown in the table below. The first three factors represent $99.937 \%$ of the expressed variance (Table 1). These factors include the maximum variance of the expressed and are sufficient to accurately translate the information. The correlation matrix between the variables is presented by Table 2 .

Table 1. Eigen values of ACP

\begin{tabular}{|c|c|c|c|c|}
\hline Factors & Eigen values & $\begin{array}{c}\text { \% of the total } \\
\text { variance } \\
\text { expressed }\end{array}$ & $\begin{array}{c}\text { Cumulative own } \\
\text { value }\end{array}$ & $\begin{array}{c}\text { Cumulative } \\
\text { variance }\end{array}$ \\
\hline $\mathbf{1}$ & 5.03 & 71.862 & 5.03 & 71.862 \\
\hline $\mathbf{2}$ & 1.566 & 22.376 & 6.596 & 94.238 \\
\hline $\mathbf{3}$ & 0.399 & 5.699 & 6.995 & 99.937 \\
\hline
\end{tabular}


Table 2. Correlation matrix between the different parameters measured

\begin{tabular}{c|ccccccc}
\multicolumn{1}{c}{} & $\mathbf{p H}$ & Conductivity & Salinity & TDS & Turbidity & TSS & CDO \\
\hline $\mathbf{p H}$ & 1.000 & & & & & & \\
Conductivity & -0.437 & 1.000 & & & & & \\
Salinity & -0.533 & $\mathbf{0 . 9 9 0}$ & 1.000 & & & & \\
TDS & -0.465 & $\mathbf{0 . 9 9 9}$ & $\mathbf{0 . 9 9 4}$ & 1.000 & & & \\
Turbidity & -0.091 & 0.673 & 0.644 & 0.667 & 1.000 & & \\
TSS & -0.028 & 0.720 & 0.678 & 0.710 & $\mathbf{0 . 9 9 0}$ & 1.000 & \\
CDO & 0.125 & 0.618 & 0.557 & 0.605 & $\mathbf{0 . 9 7 4}$ & $\mathbf{0 . 9 8 6}$ & 1.000 \\
\hline
\end{tabular}

The correlation coefficient for conductivity-salinity couples conductivity-TDS, salinity, TDS, Turbidity-TSS, Turbidity, CDO, TSS, and CDO is very strong ( $r>0.8$ ). For those couples Turbidity-conductivity, turbiditysalinity, turbidity-TDS, TSS-conductivity, TSS-salinity, TDS-TSS, CDO-conductivity, salinity and CDO-TDS are strong $(0.5<\mathrm{r}<0.8)$. Other correlations between the measured parameters are medium or low.

Positive correlations put in evidence suggests the one hand, a high amount of inorganic ions in groundwater and secondly, high solid suspended in water. All this has led to a very high turbidity. The negative correlation recorded between $\mathrm{pH}$ and other parameters have already been observed by the work of [13] in groundwater. Analysis of CPA variables in F1-F2 factorial design is presented in Figure 11. This graph shows two major groupings of parameters studied in water sampling points.

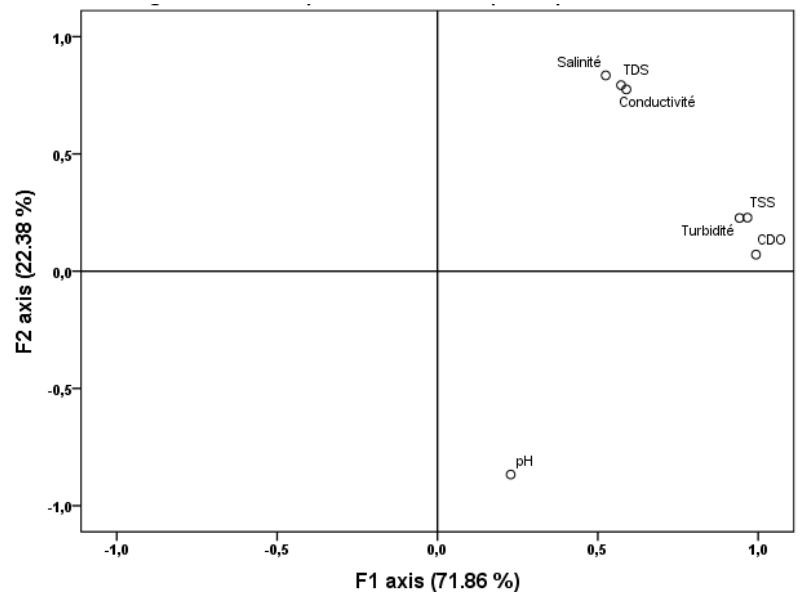

Fig. 11. Analysis in the factorial F1-F2.

The correlation formed by the axes F1 and F2 give $94.24 \%$ of the total information. The first grouping which takes into account the salinity, conductivity and TDS highlights a water mineralization. The second grouping that supports counted turbidity, TSS and COD could translate water pollution by organic matter. Similar Results found by [15].

The dendrogram (Figure 12) from the ascending hierarchical classification (CHA) to set out two main groupings of variables. The first family considers the $\mathrm{pH}$, salinity, conductivity and TDS translated mineralization related to the leaching phenomenon. The second grouping consists of turbidity, TSS and COD highlights the organic matter in the water. 


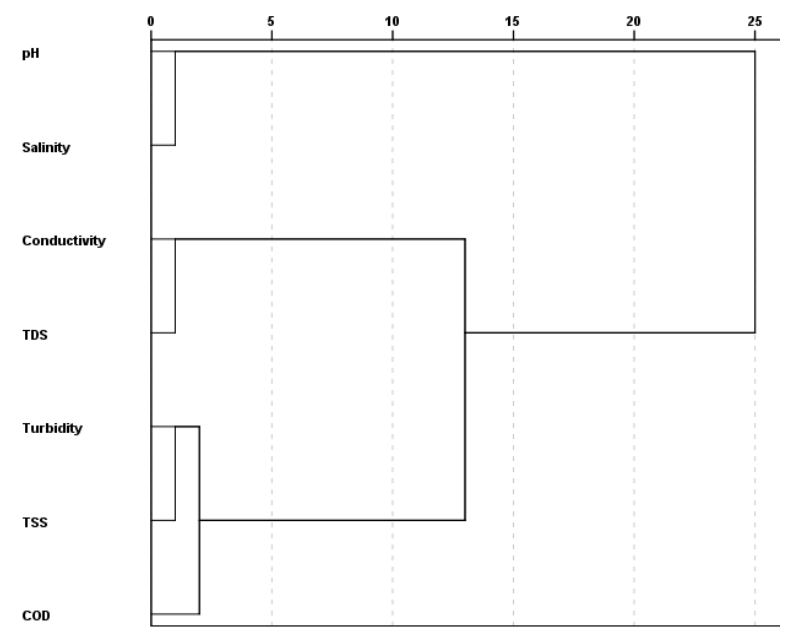

Fig. 12. Dendrogram of water quality parameters of industrial discharge.

The classification of water sampling points on the site by similarity in the context of environmental monitoring is given in Figure 13. This dendrogram shows two clusters. The first concerns points P3, P4, P2 and P1 and P5 second points. To monitor the groundwater quality of this release, it is important to choose a reporting point in each grouping.

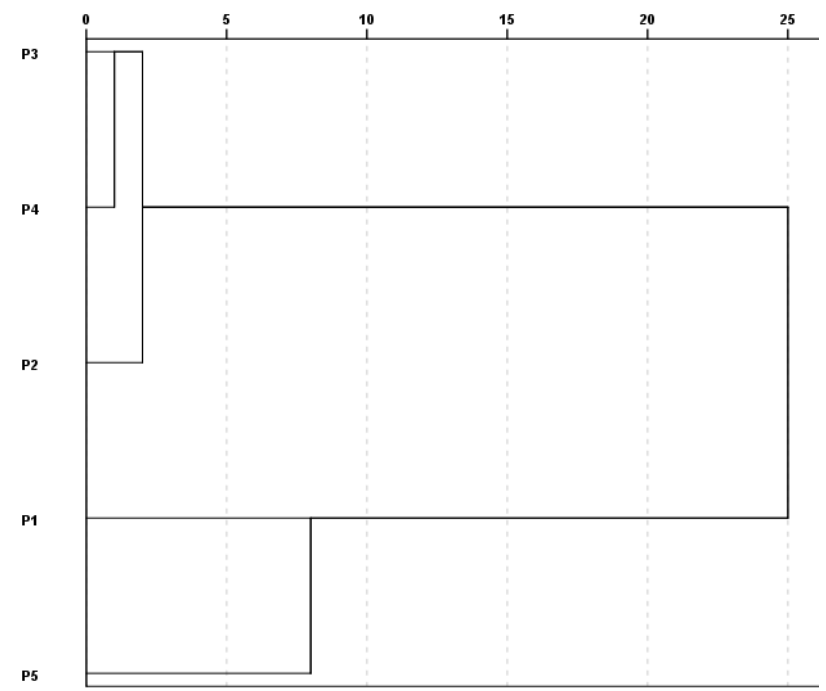

Fig. 13. Dendrogram classification of sampling points on the industrial landfill site.

\section{CONCLUSIONS}

The data collected during this study helped to paint a picture of the physical and chemical quality of groundwater in this industrial landfill from Bacau (East Romania). In light of the results obtained in terms of physicochemical parameters measured in the water, there is the existence of deterioration in water quality. Indeed, the $\mathrm{pH}$ of the water is acceptable for the survival of living organisms, turbidity, TSS, TDS, COD meanwhile remain very high at all five sampling points. Positive correlations ( $r>0.8)$ were also noted between these parameters. The practiced cluster analysis confirms this and allows to correlate the degree of water mineralization and the presence of metallic elements in the water. Indeed, very high TDS keeps the conductivity of water to values as high.

\section{Acknowledgments}

The paper was written during the postdoctoral research financed by Romanian Government through the "Eugen Ionescu" scholarship. The authors thank the Department of Environmental Engineering and Mechanical 
Engineering, Vasile Alecsandri” University of Bacau, Romania to have at their disposal the equipment used to collect data and samples in the field work.

\section{REFERENCES}

[1] Viman, O., Oroian, I., Damaging effects of overall water pollution, ProEnvironment, no. 3, 2010, p. 113-115. [2] Mangenda, H.H., Nedeff, V., Barsan, N., Moşneguțu, E.F., Chitimus, D., Rusu, D., Aspects regarding the Kinshasa urban landfills assessment and proposals for sustainable development, Journal of Engineering Studies and Research, vol. 21, no. 1, 2015, p. 48-57.

[3] Mangenda, H.H, Nedeff, V., Barsan, N., Mosnegutu, E., Tomozei, C., Municipal waste management in Limete, Mont Amba District of Kinshasa, Democratic Republic of the Congo, Journal of Engineering Studies and Research, vol. 20, no. 2, 2014, p. 39-45.

[4] Barsan, N, Nedeff, V., Mosnegutu E.F., Panainte, M. Heat balance components of a small sequencing batch reactor applied for municipal wastewater treatment, Enviromnental Engineering and Management Journal, vol. 11. no. 12, 2012, p. 2133-2140.

[5] Barsan, N., Nedeff, V., Lazar, G. Current stage of domestic wastewater treatment in small plants. Journal of Engineering Studies and Research, vol. 17, no. 4, 2011, p. 13-23.

[6] Camargo, J., Alonso, A., Ecological and toxicological effect of inorganic nitrogen pollution in aquatic ecosystems: A global assessment, Environment International, vol. 32, 2011, p. 13-23.

[7] http://www.anpm.ro/documents/14011/2497304/inchidere+depozit+zc+Dana.pdf/44d4ef4b-c70d-45b9-9c6a9ba99ac487ae (26.08.2016).

[8] Association Française de Normalisation, Qualité de l'eau, Tome 1: Terminologie, échantillonnage et évaluation des methods, 3e edition, 1997, Paris, France.

[9] Romania standards, establishing standards for water potability of groundwater, H.G. no. 53, 2009.

[10] Normes françaises, Arrêté N1639CM fixant les normes de potabilité des eaux destinées à la consommation humaine distribuées par les réseaux, fontaines et citernes à usage collectif, 1999.

[11] Normes marocaines, Bulletin officiel N5062 du 30 ramadan 1423 fixant les normes de potabilité à la consommation humaine, 2002.

[12] Kholtei, S., Physico-chemical characterization of wastewater from the city of Settat and Berrechid and assessment of their impact on the quality of water souterraines, PhD Thesis, State University Hassan 1st, Morocco, 2002.

[13] Ahoussi, K.E., Koffi, Y.B., Kouassi, A.M., Soro, G., Biemi, J., Étude hydrochimique et microbiologique des eaux de source de l'ouest montagneux de la Côte d'Ivoire: Cas du village de Mangouin-Yrongouin (souspréfecture de Biankouman), Journal of Applied Bioscience, vol. 63, 2013, p. 4703-4719.

[14] Degremont, S.A., Technical memento of water, the fiftieth edition, 9th edition. Lavoisier (publisher), Paris, France, volumes 1 and 2, 1989.

[15] Davis, J.C., Statistics and data analysis in geology. 2e edition, WILEY, New York, SUA, 1984.

[16] Domenico, P.A., Schwartz, F.W., Physical and chemical hydrogeology, Wiley international, New-York, SUA, 1990.

[17] El Amrani-Paaza, N., Benavente, J., Cruzsa Njulian, J.J., Aplicación del análisis de componentes principales al estudio de las caracteristicas fisico-quimicas de las aguas del delta del rio Adra (Almeria, España), Boletin Geologico y Minero, vol. 3, 1994, p. 478-484. 